\title{
PENCATATAN PERKAWINAN DI INDONESIA PERSPEKTIF USHUL FIKIH
}

\author{
Nenan Julir \\ Fakultas Syariah IAIN Bengkulu \\ J. Raden Fatah Pagar Dewa Bengkulu \\ Email: nenan.dailis@gmail.com
}

\begin{abstract}
One of the interesting provisions to be reviewed in Act No. 1 of 1974 is article 2 paragraph (2): "Every marriage is recorded according to the prevailing laws and regulations". This Law was promulgated on January 2, 1974 and is effective since the issuance of Government Regulation no. In fact, the provisions stipulated in Article 2 paragraph (2) still remain polemic, because there are still many people who have held marriage, but still do not register their marriage to the Officer of Marriage Certificate (VAT) Religious Affairs office. Among Muslims, there is still a firm hold on the understanding that marriage is legal if done according to Islamic law, there is no record and no letter or deed of marriage, because since the time of the Prophet, friend, until the 18th century AD no marriage records were recorded. Therefore, it is necessary to review the recording of this marriage in the perspective of ushul fiqh. From the results of this study. it can be concluded that marriage registration as regulated in Act No. 1 of 1974 when viewed through ushul fiqh fiqh, it was based on mashlahah mursalah.
\end{abstract}

Keywords: marriage recording, mashlahah mursalah, Ushul Fiqh

\begin{abstract}
Abstrak: Salah satu ketentuan yang menarik untuk dikaji dalam undang-undang No 1 tahun 1974 adalah pasal 2 ayat (2): “Tiap-tiap perkawinan dicatat menurut peraturan perundang-undangan yang berlaku”. Undang-Undang ini telah diundangkan pada tanggal 2 Januari 1974 dan berlaku efektif sejak dikeluarkan Peraturan Pemerintah No. 9 Tahun 1975 pada tanggal 1 April 1975. Namun, sampai saat ini ketentuan yang diatur dalam Pasal 2 ayat (2) tersebut masih menyisakan polemik, karena masih banyak orang yang telah melangsungkan perkawinan, tapi tetap tidak mencatatkan perkawinannya pada Pegawai Pencatat Nikah (PPN) Kantor Urusan Agama. Di kalangan umat Islam, masih ada yang berpegang teguh pada pemahaman bahwa perkawinan sudah sah apabila dilaksanakan menurut ketentuan hukum Islam, tidak perlu ada pencatatan dan tidak perlu ada surat atau akta nikah, karena sejak masa Rasulullah saw, sahabat, sampai abad ke-18 M tidak dikenal adanya pencatatan perkawinan. Oleh sebab itu, perlu dikaji kembali tentang pencatatan perkawinan ini dalam perspektif ushul fikih. Dari hasil penelitian ini. dapat disimpulkan bahwa pencatatan perkawinan yang diatur dalam UU nomor 1 tahun 1974 bila ditinjau melalui ilmu ushul fikih, ternyata penetapannya berdasarkan pada mashlahah mursalah.
\end{abstract}

Kata kunci: pencatatan perkawinan, mashlahah mursalah, Ushul Fikih

\section{Pendahuluan}

Perkawinan bagi manusia bukan hanya sebagai pernyataan (statemen) yang mengandung keizinan untuk melakukan hubungan seksual sebagai suami isteri, tetapi juga merupakan tempat berputarnya hidup kemasyarakatan. Dengan demikian, perkawinan mempunyai arti yang amat penting dalam kehidupan manusia dan merupakan pola kebudayaan untuk mengendalikan serta membentuk pondasi yang kuat dalam kehidupan rumah tangga.

Perkawinan mempunyai fungsi dan makna yang kompleks. Dari kompleksitas fungsi dan makna itulah, maka perkawinan sering dianggap sebagai peristiwa yang sakral (suci). Dan oleh karena itu pula, perkawinan tidak boleh dilakukan secara sembarangan, tetapi harus memenuhi ketentuan yang sudah ditetapkan. Dengan kompleksitas makna dan fungsi yang terkandung di dalam perkawinan 
itu pula sehingga pemerintah atau negara perlu untuk ikut terlibat dalam pengaturannya. Salah satu bentuk keterlibatan pemerintah atau negara dalam masalah perkawinan adalah dengan diundangkannya Undang-Undang No. 1 Tahun 1974 tentang Perkawinan.

Salah satu ketentuan yang diatur di dalam undang-undang tersebut yang menarik untuk dikaji adalah ketentuan di dalam Pasal 2 ayat (2) yang berbunyi: "Tiap-tiap perkawinan dicatat menurut peraturan perundang-undangan yang berlaku".

Meskipun Undang-Undang No. 1 Tahun 1974 ini telah diundangkan pada tanggal 2 Januari 1974 dan berlaku efektif sejak dikeluarkan Peraturan Pemerintah No. 9 Tahun 1975 pada tanggal 1 April 1975, namun sampai saat ini ketentuan yang diatur dalam Pasal 2 ayat (2) tentang perncatatan perkawinan, masih menimbulkan banyak persoalan, karena masih banyak orang yang telah melangsungkan perkawinan namun ia tidak mencatatkan perkawinannya pada Pegawai Pencatat Nikah (PPN) Kantor Urusan Agama, baik karena faktor ketidaktahuan dan ketidaksadaran akan pentingnya dokumen perkawinan maupun karena adanya maksud untuk memanfaatkan celah hukum bagi mereka yang akan melangsungkan poligami, menjaga kelangsungan tunjangan suami bagi wanita yang telah bercerai, atau karena masalah biaya pencatatan perkawinan bagi mereka yang tidak mampu.

Di samping faktor tersebut di atas, di kalangan umat Islam masih ada yang berpegang teguh pada pemahaman bahwa perkawinan sudah sah apabila dilaksanakan menurut ketentuan hukum Islam, tidak perlu ada pencatatan dan tidak perlu ada surat atau akta nikah, karena sejak masa Rasulullah saw, sahabat sampai abad \pm ke $18 \mathrm{M}$ belum dikenal adanya pencatatan perkawinan, sehingga apa dasar syar'inya suatu negara menetapkan UU pengharusan pencacatan sebuah perkawinan. Oleh karena itu, pada kesempatan ini penulis mencoba membahas persoalan pencatatan per- kawinan ini dalam perspektif kajian ushul fiqh dengan harapan tulisan ini dapat memberi pencerahan.

\section{Peraturan Tentang Pencatatan Perkawinan}

Dalam Pasal 2 ayat (1) Undang-Undang No. 1 Tahun 1974 tentang Perkawinan disebutkan bahwa perkawinan adalah sah apabila dilakukan menurut hukum masing-masing agamanya dan kepercayaannya itu. Selanjutnya dalam penjelasan pasal tersebut dikemukakan bahwa tidak ada perkawinan di luar masing-masing agama dan kepercayaan itu. Kemudian dalam Pasal 2 ayat (2) Undang-Undang No. 1 Tahun 1974 tentang Perkawinan disebutkan bahwa tiap-tiap perkawinan harus dicatat menurut peraturan yang berlaku. Peraturan yang dimaksud adalah Undang-Undang No. 22 Tahun 1946 dan Undang-Undang No. 34 Tahun 1954, sedangkan kewajiban Pegawai Pencatat Nikah diatur dalam Peraturan Pemerintah No. 1 tahun 1954 dan No. 2 tahun 1955. Menurut ketentuan Pasal 2 Peraturan Pemerintah No. 9 Tahun 1975 bahwa pencatatan Perkawinan bagi yang beragama Islam dilakukan oleh Pegawai Pecatat Nikah (PPN) Kantor Urusan Agama, sedangkan pecatatan perkawinan bagi selain Islam dilakukan oleh Pencatat Perkawinan pada Kantor Catatan Sipil.

Proses pencatatan perkawinan itu diawali dengan pemberitahuan kehendak untuk melangsungkan perkawinan kepada Pegawai Pencatat Nikah di tempat di mana perkawinan itu akan dilangsungkan sekurang-kurangnya 10 (sepuluh) hari kerja sebelum perkawinan dilangsungkan baik secara lisan maupun tulisan oleh calon mempelai, atau oleh orang tua atau wakilnya (Pasal 3 dan 4 PP No. 9 Tahun 1975).

Apabila syarat-syarat formiil telah terpenuhi dan tidak ada halangan hukum baik hukum agama maupun undang-undang bagi calon mempelai untuk melangsukan perkawinan, maka sesaat sesudah akad nikah dilangsungkan, kedua belah pihak (suami-isteri) menandatangani akta 
perkawinan yang telah disiapkan oleh Peagawai Pencatat. Dengan penandatangan tersebut, maka perkawinan telah tercatat secara resmi dan masing-masing pasangan suami isteri akan mendapatkan kutipan Akta Nikah atau Buku Nikah sebagai bukti autenktik tentang terjadinya perkawinan (Pasal 13 Peraturan Pemerintah No. 9 Tahun 1975 dan Pasal 7 ayat (1) Kompilasi Hukum Islam).

Dengan diterbitkannya Akta Nikah dan masing-masing pasangan suami isteri telah mendapatkan buku nikah, maka perkawinan itu telah mendapatkan legalitas dan perlindungan serta ada jaminan kepastian hukum, termasuk memberikan perlindungan hukum terhadap akibat yang timbul kemudian dari perkawinan itu, seperti hak dan kewajiban antara suami dan isteri secara timbal balik, harta bersama (gonogini), status anak, dan sebagainya.

\section{Urgensi Pecatatan Perkawinan}

Seperti yang telah disebutkan di atas, bahwa dengan dicacatkannya perkawinan pada Pegawai Pencacat Nikah (PPN) pada Kantor Urusan Agama bagi yang beragama Islam dan pada Kantor Catatan Sipil bagi yang beragama selain Islam, maka perkawinan itu telah mendapatkan kepastian dan perlindungan hukum, termasuk terhadap akibat-akibat yang timbul kemudian dari perkawinan itu.

Seorang wanita yang menikah dengan seorang laki-laki dan perkawinannya tidak dicatatkan di Pegawai Pencatat Nikah (PPN), apabila suaminya lalai atau mengabaikan kewajibannya, jika ia akan menuntut suaminya untuk memenuhi kewajibannya di pengadilan seperti yang diatur dalam Pasal 34 ayat (3) Undang-Undang No. 1 Tahun 1974 tentang Perkawinan atau akan menggugat suaminya di pengadilan karena telah melakukan penelantaran sebagaimana diatur dalam Pasal 9 Undang-Undang No. 23 Tahun 2004 tentang Penghapusan Kekerasan dalam Rumah Tangga (KDRT), maka ia akan mengalami kesulitan karena tidak adanya bukti autentik tentang adanya hubungan hukum berupa perkawinan antara dia dan suaminya. Dari sini jelas, bahwa yang menjadi korban atau pihak yang dirugikan akibat perkawinan yang tidak tercatat adalah pihak wanita.

Pasangan suami isteri yang mempunyai anak, sedangkan perakwinannya tidak tercatat dan akan membuatkan akta kelahiran anaknya pada Kantor Catatan Sipil akan mengalami kesulitan karena salah satu kelengkapann administrasi yang harus dipenuhi adalah foto kopi Kutipan Akta Nikah orang tuanya. Bagi pasangan suami isteri yang tidak mempunyai Buku Nikah, Kantor Catatan Sipil akan menerbitkan Akta Kelahiran anak tanpa mencantumkan nama bapaknya dalam akta tersebut.

Penerbitan akta kelahiran secaman itu, sama dengan akta kelahiran seorang anak yang tidak mempunyai ayah atau anak di luar nikah karena hanya dinisbahkan kepada ibunya. Berbeda halnya dengan akta kelahiran anak yang perkawinan orang tuanya tercatat, maka nama kedua orang tuanya akan tercantum di dalam akta kelahirannya.

Pasangan suami isteri yang tidak memiliki Buku Nikah karena perkawinan mereka tidak dicacatkan, yang akan melakukan perceraian di pengadilan, maka memerlukan proses yang lebih lama daripada orang yang meiliki Buku Nikah. Sebab sebelum pemeriksaan dalil-dalil yang menjadi alasan untuk bercerai, pengadilan terlebih dahulu akan mengumumkan melalui media mssa sebanyak 3 (tiga) kali dalam tenggang waktu 3 (tiga) bulan, minimal satu bulan setelah pengumuman terakhir pengadilan baru akan memeriksa status perkawinannya, apakah sah atau tidak. Apabila dalam proses pemeriksaan ternyata perkawinan mereka telah memenuhi syarat dan rukun perkawinan, maka perkawinan mereka akan diitsbatkan (Pasal 7 ayat (3) huruf a Kompilasi Hukum Islam). Apabila tidak memenuhi syarat dan rukun perkawinan, maka gugatan atau permohonan mereka untuk bercerai tidak diterima oleh pengadilan. 
Dari paparan di atas, tergambar bahwa ketentuan pencatatan perkawinan yang diatur dalam Pasal 2 ayat (2) Undang-Undang No. 1 Tahun 1974 tentang Perkawinan, merupakan hal yang sangat urgen karena dapat memberikan jaminan perlindungan dan kepastian hukum terhadap perkawinan dan memberikan jaminan ketertiban dalam kehidupan bermasyarakat. Oleh karena itu, ketentuan Pasal 2 ayat (2) tersebut, mempunyai fungsi mengatur dan merekayasa interaksi sosial masyarakat.

Paling tidak manfaat pencatatan nikah dapat diuraikan sebagai berikut:

a. Menjadi alat bukti sah dan otentik telah terjadinya perkawinan antara seorang lakilaki dan seorang perempuan, sehingga bisa diperlihatkan dan dipergunakan untuk pengurusan administrasi kependudukan/pemerintahan, seperti: pengurusan KTP, Kartu Keluarga, Akte Kelahiran Anak, kelengkapan persyaratan kependidikan atau kepegawaian, dan lain-lain.

b. Menjadi alat bukti sah dan otentik ketika berperkara di Pengadilan Umum/Pengadilan Agama.

c. Menjadi alat bukti sah dan otentik untuk mendapatkan perlindungan hukum berkaitan dengan hak-hak sebagai akibat hukum adanya perkawinan, seperti nafkah dan tempat tinggal istri/anak, nafkah iddah, hadhanah (hak pemeliharaan anak), warisan, dan lain-lain.

Sebaliknya bila pernikahan tidak dicatatkan, maka kerugian yang akan didapat diantaranya:

a. Tidak ada perlindungan hukum terhadap perkawinan karena bagi negara dipandang tidak terjadi perkawinan, sesuai Jurisprudensi Mahkamah Agung Putusan Nomor 1948/K/ Pid/1991 tanggal 18 Desember 1991)

b. Ditolak berperkara tentang masalah hukum keluarga (nikah, talak, rujuk, hadhanah, iddah, harta gono-hini dan waris) di Pengadilan Agama karena perkawinan tidak dapat dibuktikan dengan bukti yang otentik, kecuali dilakukan itsbat nikah.

c. Pihak istri sewaktu-waktu dapat diceraikan suaminya atau suami sewaktu-waktu dapat berpoligami tanpa, bahkan dapat mengingkari perkawinan dan anak-anak hasil perkawinan tersebut, sedangkan istri tidak memiliki kekuatan hukum untuk melakukan perlawanan hukum di Pengadilan Agama.

d. Tidak ada alat bukti sah untuk menegaskan asal-usul anak dan keturunan.

e. Sulit melakukan pengurusan administrasi kependudukan.

\section{Pencatatan Nikah Dalam Kajian Ushul Fiqh}

Pencatatan nikah, bila dilihat dari kaidah perumusan hukum Islam, maka dapat ditinjau dari beberapa sisi:

\section{Nash}

Mengingat persoalan pencatatan nikah merupakan persoalan baru, ia hadir karena tuntutan zaman, maka dapat dipastikan bahwa persoalan ini tidak ditemukan secara tegas (qathi) dan jelas (sharih) dalam nash (alQuran dan hadis). Walaupun begitu, bukan berarti persoalan ini luput dari perhatian syara'. Penjelasan persoalan ini akan ditemukan dalam makna umum dari kandungan nash karena ada keserasian makna, baik disebut dengan istilah qiyas, ijma', mashlahah mursalah, maupun maqashid syar'iyah.

\section{Qiyas}

Qiyas menurut bahasa berarti "mengukur sesuatu dengan sesuatu yang lain untuk diketahui adanya persamaan antara keduanya”. Menurut istilah Ushul fiqh qiyas adalah:

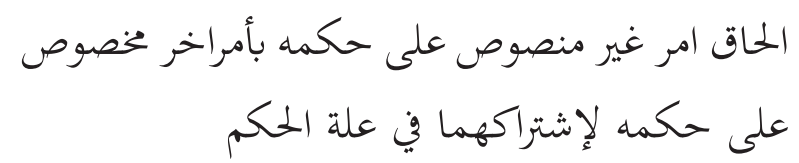

"Menghubungkan (menyamakan hukum) sesuatu 
yang tidak ada ketentuan bukumnya dengan sesuatu yang ada ketentuan hukumnya karena ada persamaan illat antara keduanya".

Di sini yang tidak ada ketentuan hukumnya adalah masalah pencatatan nikah (disebut furu'), sementara persoalan yang ada ketentuan hukumnya adalah persoalan muamalah hutangpiutang (disebutaal-ashl). Sebagaimana dijelaskan Alquran suarat al-Baqarah ayat 282 yang berbunyi:

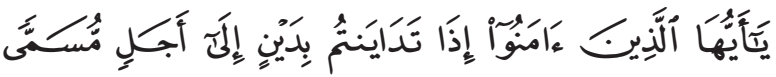

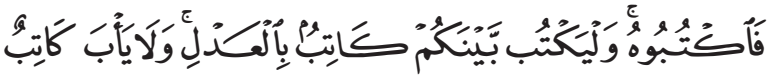

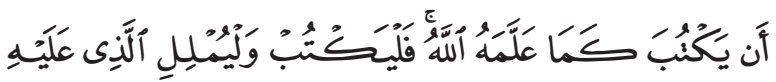

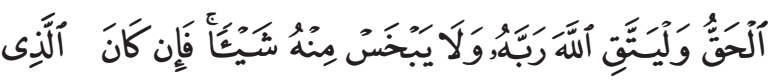

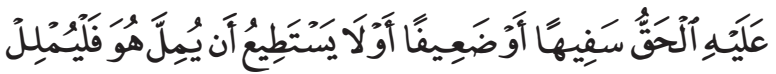

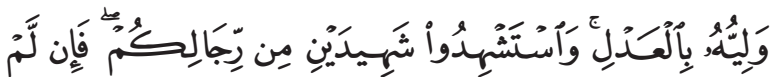

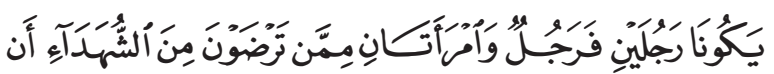

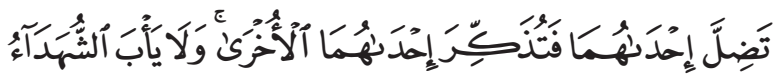

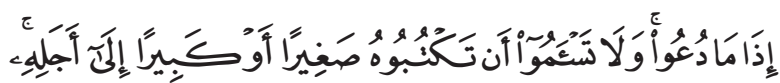

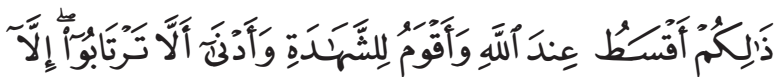

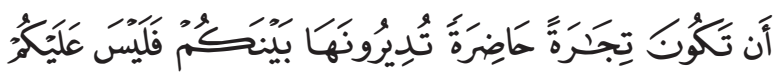

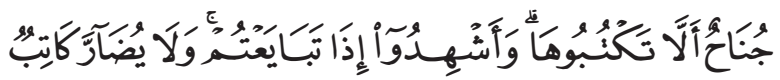

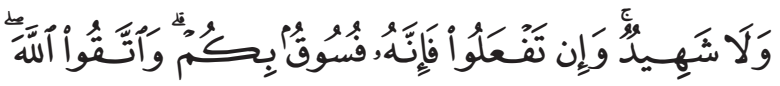

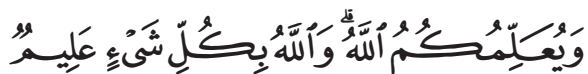

"Hai orang-orang yang beriman, apabila kamu bermu'amalah tidak secara tunai untuk waktu yang ditentukan, hendaklah kamu menuliskannya. Dan hendaklah seorang penulis di antara kamu menuliskannya dengan benar. Dan janganlah penulis enggan menuliskannya sebagaimana Allah mengajarkannya, maka hendaklah ia menulis, dan hendaklah orang yang berhutang itu mengimlakkan (apa yang akan ditulis itu), dan hendaklah ia bertakwa kepada Allah Tuhannya,

${ }^{1}$ Muhammad Abu Zahrah, Ushul al- Fiqh, (Kairo: Dar alFikr, 1957), h. 82. dan janganlah ia mengurangi sedikitpun daripada hutangnya. Jika yang berhutang itu orang yang lemah akalnya atau lemah (keadaannya) atau dia sendiri tidak mampu mengimlakkan, maka hendaklah walinya mengimlakkan dengan jujur. Dan persaksikanlah dengan dua orang saksi dari orang-orang lelaki (di antaramu). Jika tak ada dua oang lelaki, maka (boleh) seorang lelaki dan dua orang perempuan dari saksi-saksi yang kamu ridhai, supaya jika seorang lupa maka yang seorang mengingatkannya. Janganlah saksi-saksi itu enggan (memberi keterangan) apabila mereka dipanggil; dan janganlah kamu jemu menulis hutang itu, baik kecil maupun besar sampai batas waktu membayarnya. Yang demikian itu, lebih adil di sisi Allah dan lebih menguatkan persaksian dan lebih dekat kepada tidak (menimbulkan) keraguanmu. (Tulislah mu'amalahmu itu), kecuali jika mu'amalah itu perdagangan tunai yang kamu jalankan di antara kamu, maka tidak ada dosa bagi kamu, (jika) kamu tidak menulisnya. Dan persaksikanlah apabila kamu berjual beli; dan janganlah penulis dan saksi saling sulit menyulitkan. Jika kamu lakukan (yang demikian), maka sesungguhnya hal itu adalah suatu kefasikan pada dirimu. Dan bertakwalah kepada Allah; Allah mengajarmu; dan Allah Maha Mengetahui segala sesuatu."

Dalam ayat di atas, terdapat anjuran untuk mencatat semua transaksi muamalah, tidak hanya dicatat tetapi juga harus dipersaksikan oleh dua orang laki-laki. Hal ini untuk menjaga jangan sampai ada kekeliruan, keraguan, dan ketidakpastian. Dalam tafsir al-Quran ditemukan keterangan bahwa masuk dalam makna muamalah seperti melakukan jual beli, hutang piutang, atau sewa mwnyewa dan sebagainya. Sebagaimana diketahui bahwa pernikahan juga merupakan bagian dari muamalah, malah pernikahan bukanlah muamalah biasa akan tetapi perjanjian yang sangat kuat, seperti disebutkan dalam al-Qur'an surat an-Nisa' ayat 21:

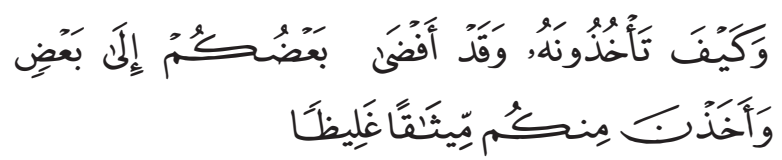


"Bagaimana kamu akan mengambilnya kembali, padahal sebagian kamu Telah bergaul (bercampur) dengan yang lain sebagai suami-isteri. dan mereka (isteri-isterimu) Telah mengambil dari kamu perjanjian yang kuat".

Jadi kesamaan antara muamalah pernikahan dengan muamlah jual beli atau hutang piutang adalah bahwa di dalamnya ada kesamaan rukun, terutama adanya orang yang melakukan akad, adanya saksi, dan sighat akad. Dengan demikian pencatatan nikah yang tidak ada nash syarih yang menjelaskannya dapat diqiyaskan pada muamalah hutang piutang yang ada penjelasannya dalam nash, karena adanya kesamaan illah di antara keduanya, yaitu bukti keabsahan perjanjian/ transaksi muamalah (bayyinah syar'iyah). Bila akad hutang piutang atau hubungan kerja yang lain harus dicatatkan, mestinya akad nikah yang begitu luhur, agung, dan sakral lebih utama lagi untuk dicatatkan. Dengan demikian, bahwa pencatatan akad nikah dianjurkan oleh Islam sebagaimana perintah pencatatan akad hutangpiutang atas dasar qiyas. Dalam kaidah fikihnya dinyatakan:

$$
\text { الثابت بالبرهان كالثابت بالعيان }
$$

"Sesuatu yang telah ditetapkan berdasarkan bukti (keterangan) sepadan dengan yang telah di tetapkan berdasarkan kenyataan"2

\section{3. ljma'}

Dalam konsep ushul fikih, ijma' yang dapat diterima sebagai dalil hukum adalah ijma' para sahabat. Hal ini dipahami dari makna ijma' itu sendiri, yaitu kesepakatan seluruh ulama yang ada pada satu masa akan suatu masalah ${ }^{3}$. Yang bisa diketahui bahwa seluruh ulama yang ada pada satu masa sepakat akan suatu masalah tentu masa sahabat saja, disamping orangnya sedikit, umat Islam ketika itu hidup pada wilayah yang berdekatan. Hal ini memudahkan untuk

${ }^{2}$ Sayyid Qutb, al-Adalah al-Ijtimaiiyah fi al-Islam, (Beirut: Dar al-Kitab al-Arabi, t.th), h. 223.

${ }^{3}$ Saif al-Din Abi al-Hasan Ali bin Ali, al-Ihkam Fi Ushul alAhkam, (Kairo: Muassasa al-Halabi, 1967), h. 132. menjalin komumikasi antar sesama.

Adapun ijma' di era sekarang, tentu tidak akan ditemukan dalam pengertian yang seperti itu, karena sangat sulit terjadi kesepakatan seluruh ulama yang hidup pada satu masa tentang suatu masalah, justru yang menjadi ciri khas ulama yang hidup di zaman sekarang adalah selalu memilki pendapat yang berbeda antara satu sama lainnya sehingga munculah istilah "perbedaan adalah rahmat" sesuatu yang tidak bisa dihindari tetapi harus bisa dimaklumi.

Walaupun kesepakatan seluruh ulama tidak mungkin terjadi untuk hari ini, namun ada cara lain yang ditempuh para ulama dalam menyelesaikan persoalan-persoalan baru, di antaranya melalui mu'tamar, konferensi, lokakarya, dan lain sebagainya. Terkait pencatatan nikah dalam UU nomor 1 tahun 1974 tentang perkawinan, para alim ulama Indonesia telah melakukan lokakarya pada tanggal 2 s.d. 5 Februari 1991. Hasil dari lokakarya tersebut bahwa ketentuan pencatatan nikah dapat diterima dengan baik. Walaupun tidak seluruh ulama sepakat tapi dapat dikatakan bahwa sebagian besar ulama Indonesia sepakat bahwa pencatatan nikah merupakan bagian dari hukum yang wajib ditaati oleh umat Islam.

\section{Mashlahah Mursalah}

Mashlahah mursalah adalah kemashlahatan yang tidak dianjurkan oleh syari'at dan juga tidak dilarang oleh syari'at, semata-mata hadir atas dasar kebutuhan masyarakat. Penetapan hukum atas dasar kemaslahatan merupakan salah satu prinsip dalam penetapan hukum Islam, sebagaimana disebutkan dalam kaidah:

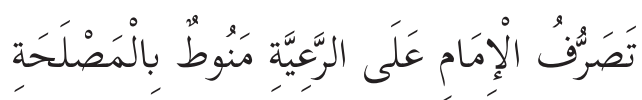

"Suatu tindakan pemerintah terhadap rakyatnya dilakukan atas dasar maslahat."

${ }^{4}$ Ibnu Nujaim, al-Hanafi, Zayn al-Abidin ibn Ibrahim, alAsybah wa al-Nazha'ir, (Damaskus: Dar al-Fikr, 1983), Cet. ke1, h. 137. 
Atas dasar kemashlahatan, di beberapa negara muslim, termasuk di Indonesia, telah dibuat aturan yang mengatur perkawinan dan pencatatannya. Hal ini dilakukan untuk ketertiban pelaksanaan perkawinan dalam masyarakat, adanya kepastian hukum, dan untuk melindungi pihak-pihak yang melakukan perkawinan itu sendiri serta akibat dari terjadinya perkawinan, seperti nafkah isteri, hubungan orang tua dengan anak, kewarisan, dan lainlain. Melalui pencatatan perkawinan yang dibuktikan dengan akte nikah, apabila terjadi perselisihan di antara sumai isteri, atau salah satu pihak tidak bertanggung jawab, maka yang lain dapat melakukan upaya hukum guna mempertahankan atau memperoleh haknya masing-masing, karena dengan akte nikah suami isteri memiliki bukti otentik, legal formal atas perkawinan yang terjadi antara mereka.

Lahirnya teori kemaslahatan dalam rangka mengantisipasi perubahan dan tuntutan zaman, agar hukum Islam tetap sejalan dengan maqashidus syarinya. Perubahan terhadap sesuatu, termasuk institusi perkawinan dengan dibuatnya undangundang atau peraturan lainnya, adalah merupakan kebutuhan yang tidak bisa dihindarkan, ia lahir karena tuntutan keadaan.

Pencatatan perkawinan selain substansinya untuk mewujudkan ketertiban hukum juga mempunyai manfaat preventif, seperti supaya tidak terjadi penyimpangan rukun dan syarat perkawinan. Menghindarkan terjadinya pemalsuan identitas para pihak yang akan kawin, seperti laki-laki yang mengaku jejaka tetapi sebenarnya dia mempunyai isteri dan anak. Tindakan preventif ini dalam peraturan perundangan direalisasikan dalam bentuk penelitian persyaratan perkawinan oleh Pegawai Pencatat, seperti yang diatur dalam Pasal 6 PP Nomor 9 Tahun 1975.

Dengan demikian mencatatkan perkawinan mengandung manfaat atau kemaslahatan, kebaikan yang besar dalam kehidupan masyarakat. Sebaliknya apabila perkawinan tidak diatur secara jelas melalui peraturan perundangan dan tidak dicatatkan akan digunakan oleh pihakpihak yang melakukan perkawinan hanya untuk kepentingan pribadi dan merugikan pihak lain terutama isteri dan anak-anak.

Selain itu, tujuan perkawinan sebagaimana tercantum dalam Alquran surat al-Rum ayat 21 adalah terwujudnya sebuah keluarga (rumah tangga) yang sakinah, mawaddah, dan rahmah, serta bahagia dan kekal. Untuk mewujudkan tujuan yang mulia tersebut, banyak faktor yang harus dipenuhi, salah satu di antaranya adalah adanya legalitas dari negara. Untuk mendapatkan legalitas dari negara, pasal 2 ayat (2) Undang-Undang No. 1 Tahun 1974 tentang Perkawinan mengatur bahwa tiap- tiap perkawinan dicatatkan menurut peraturan perundang-undangan yang berlaku. Dalam pasal 5 ayat (1) Kompilasi Hukum Islam mengharuskan agar setiap perkawinan yang dilakukan dicatatkan agar terjamin ketertiban perkawinan bagi masyarakat.

Bukti autentik bahwa perkawinan telah tercatat adalah dikeluarkannya Buku Nikah oleh instansi yang bewenang (Kantor Urusan Agama ). Akta Nikah itu diibaratkan Surat Izin Mengemudi (SIM) bagi pengenndara sepeda motor atau mobil. Bagi pengendara yang memiliki SIM akan merasa aman berkendaraan di jalan tanpa ada rasa khawatir kena tilang oleh Polantas. Demikian halnya bagi pasangan suami isteri yang memiliki Buku Nikah, akan merasa aman dan tenteram dalam kehidupan rumah tangganya tanpa ada rasa khawatir akan dirazia oleh Sat Pol PP apabila mnginap di hotel atau digerebeg oleh massa karena dicurigai kumpul kebo dan sebagainya.

Oleh sebab itu, pencatatan perkawinan pada hakikatnya berujuan untuk memberikan kepastian dan perlindungan hukum bagi kedua belah pihak (suami isteri), termasuk kepastian dan perlindungan hukum terhadap akibat yang ditimbulkan dari perkawinan itu sendiri, yaitu tentang hak dan kewajiban masing-masing secara 
timbal balik, tentang anak-anak yang dilahirkan. Menurut Theo Huijbers, politik hukum bertujuan tidak hanya menjamin keadilan, melainkan juga menciptakan ketenteraman hidup dengan memelihara kepastian hukum dan untuk menangani kepentingan-kepentingan yang nyata dalam kehidupan bersama secara konkret. $^{5}$

Dalam konsep Maqashid al-Syariah, segala sesuatu yang dapat menimbulkan kemudharatan harus dihindari. Perkawinan yang tidak tercatat akan menimbulkan banyak mudharat (keburukan) bagi pasangan suami isteri maupun bagi pihak lain yang terkait dengan perkawinan tersebut. Sehubungan dengan hal tersebut, diharapkan setiap orang yang akan melangsungkan perkawinan agar tidak hanya mementingkan satu aspek saja, yaitu agama, tetapi juga perlu diperhatikan aspek-aspek keperdataannya secara seimbang agar tujuan dari perkawinan benar-benar terwujud.

Terlepas dari pandangan pro-kotra dalam menilai masalah pencatatan perkawinan yang diatur dalam Pasal 2 ayat (2) Undang-Undang No. 1 Tahun 1974 tentang Perkawinan, penulis memandang pencatatan perkawinan merupakan hal yang sangat baik dan bermanfaat karena dapat menjamin ketertiban dalam kehidupan bermasyarakat. Di samping itu, karena hukum positif telah menentukan bahwa satu-satunya bukti adanya perkawinan adalah Akta Nikah, maka percatatan perwakawinan sangat perlu dilakukan

Atas dasar pertimbangan di atas, meskipun secara formal tidak ada ketentuan ayat atau sunnah yang memerintahkan pencatatan (perkawinan), namun karena kandungan mashlahatnya sejalan dengan tindakan syara' yang ingin mewujudkan kemashlahatan manusia, Dengan demikian dapat ditegaskan bahwa pencatatan perkawinan merupakan ketentuan yang perlu diterima dan dilaksanakan oleh semua pihak

${ }^{5}$ Theo Huijbers, Filsafat Hukum, ( Yogyakarta, Kanisius, 1995), h. 118 karena memiliki landasan yang kokoh yaitu mashlahat mursalah.

Dari paparan sebelumnya dijelaskan bahwa pencatatan nikah memberikan manfaat yang begitu besar bagi kehidupan rumah tangga. Sekalipun tidak mendapat sandaran langsung dari nash, namun karena manfaat (mashlahah) yang ada di dalamnya sejalan dengan maqashid syar'iyah, maka keberadaannya harus diterima dan dilaksanakan. Hanya saja satu hal yang harus diperjelas di sini, bahwa sudah 38 tahun pencatan nikah di UU-kan namun hingga hari ini masih terjadi perdebatan dikalangan umat Islam tentang keberadaannya. Penulis melihat perdebatan yang tidak kunjung usai itu lebih disebabkan karena ketidakjelasan kedudukan pencatatan nikah itu sendiri dalam hukum perkawinan. Terlebih lagi bahasa yang digunakan dalam UU "pencatatan nikah" antara satu pasal dengan pasal lain tidak berkesusaian, sehingga melahirkan interpretasi yang berbeda, ada yang berpendapat pencatatan nikah syarat sah nikah, ada pula yang mengatakan syarat administrasi, bahkan ada yang berpendapat pencatatan nikah menjadi rukun dari sebuah perkawinan.

Di sisi lain sebagaimana diketahui bahwa dengan diUU-kannya pencatatan nikah, memberikan dampak kebaikan yang begitu besar dalam kehidupan bermasyarakat. Tidak ada yang mengingakari bahwa dengan adanya UU ini banyak hak yang terjaga dengan baik.

Melihat kenyataan ini, penulis berpendapat bahwa pencatatan nikah tidak merupakan syarat, tidak pula merupakan rukun nikah, tatapi pencatatan nikah merupakan wajib nikah, sebagaimana mahar dalam perkawinan. Diketahui mengadakan mahar dalam sebuah perkawinan adalah suatu keharusan. Akan tetapi keharusan di sini tidak merupakan syarat, tidak pula rukun tetapi ulama menggolongkannya kepada wajib nikah, karena melihat keberadaannya yang begitu urgen. Bila suatu pernikahan tidak membayar mahar, maka 
pernikahan tetap sah hanya saja suami sebagai orang yang dikenai kewajiban membayar, berdosa. Begitu juga pencatatan nikah, bila suatu pernikahan tidak dicatatkan, pernikahaannya tetap sah, hanya saja yang berdosa di sini bukan hanya suami tetapi istri juga berdosa, karena keduanya berperan mendekatkan perkawinannya kepada kemudharatan yang nyata di depan mata. Jadi konsekuensi dari tidak terpenuhi wajib nikah (dalam hal ini nikah tidak dicatatkan) bukan nikahnya tidak sah sebagaimana diklaim banyak orang selama ini, tetapi sebagai konsekuensinya pernikahan mereka tidak mendapat perlindungan hukum dari negara dan kesulitan dalam mengurus beberapa hak-haknya sebagai warga negara, termasuk hak anak yang lahir dari perkawinan mereka.

\section{Penutup}

Dari uraian sebelumnya, dapat disimpulkan bahwa pencatatan nikah yang diatur dalam UU nomor 1 tahun 1974 bila dilihat dari tinjaun ushul fiqhnya bahwa penetapanya berdasarkan kepada mashlahah mursalah. Secara teks tidak ada nash yang melarang, begitu pula sebaliknya tidak ada nash yang menganjurkannya, tetapi karena keberadaannya yang membawa banyak kebaikan, maka ia diperlukan. Sebagaiمالا يتم الواجب الا به فهو واجب mana kaidah berbunyi (sesuatu yang tidak sempurna kecuali dengan sesuatu yang lain, maka sesuatu yang lain itu pun menjadi wajib hukumnya). Dalam hal ini, tujuan suatu perkawinan tidak akan terwujud sempurna kecuali dengan sesuatu yang lain, di antaranya pernikahan tersebut harus tercatat, maka terkait dengan mencatatkan pernikahan ini menjadi wajib hukumnya. Hanya saja, wajib di sini bukan masuk ke dalam syarat atau rukun nikah, tetapi ia digolongkan kepada wajib nikah.

\section{Pustaka Acuan}

Amidi, Saif al-Din Abi al-Hasan Ali bin Ali al-, al-Ihkam Fi Ushul al-Ahkam, Kairo: Muassasah al-Halabi, 1967.

Azhari, Muhammad Tahir, Negara Hukum: Suatu Studi tentang Prinsip-Prinsipnya Dilihat dari Segi Hukum Islam, Implementasinya pada Periode Negara Madinah dan Masa Kini, Jakarta: Bulan Bintang, 1992.

Badran, Abu al-Ainaini, Ushûl al-Fighi alIslâmî, Iskandariyah: Muassasah Syabâb alJamâ'ah, t.th.

Burnu, Muhammad shidqi bin Ahmad al-, alWajiz fi Idhah qawaid al-fiqhiyah al-Kulliyah. Cet. I, Beirut: Muassasa al-Risalah,1983.

Hanafi, Ibnu Nuzaim, al-, Zayn al-abidin Ibn Ibrahim. al-Asybah wa al-Nazhäir, Damaskus: Dar al-Fikr, 1983, Cet. ke-1.

Huijbers, Theo, Filsafat Hukum, Yogyakarta, Kanisius, 1995.

Jauziyah, Ibnu al-Qayyim al-, I'lam AlMuwaqqiin, Maktabah Syamilah Edisi II

Khalaf, Abdul Wahab Ilmu Ushul al-Figh. Bandung: Gema Risalah press. 1997

Lajnah Makwanan Min "idatil Ulama' wa Fiqoha Fi Khilafatil Utsmaniyah, Majallatu al-Ahkam al-Adliyah, Maktabah Syamilah Edisi II.

Nasution, Khoiruddin, Status Wanita di Asia Tenggara: Studi Terhadap Perundangundangan Perkawinan Muslim Kontemporer di Indonesia dan Malaysia, Jakarta-Leiden: INIS, 2002.

Peraturan Pemerintah No. 9 Tahun 1975.

Ruki , Muhammad al-, Qawaid al-Figh alIslami, Beirut: Dar al-Qalam, t.th.

Salam, Izz al-Din bin Abd, Qawaid al-Ahkam fi Mashalih al-Anam, Suriah: Dar al-Jalil, 1980.

Sayyid Qutb, al-'Adalah al-Ijtima'iyah fi alIslam, Beirut: Dar al-Kitab al-Arabi, t.th.

Suyuthi, Jalaluddin bin Abd Rahman bin Abi Bakr al-. al-Asybah wa Nazhair fi Qawaid wa 
al-Furu' Fiqh al-Syafi'i. Beirut: Dar al-Kutub al-'Imiah, 1399H/1979, Cet. ke-1.

Syatibi, Abu Ishaq al-, al-Muwafaqat fi Ushul al-Syari ah. Mesir: Maktabah al-Tijariyah alKubra, t.th.
Undang-Undang No. 1 Tahun 1974 tentang Perkawinan

Zahrah, Muhammad Abu, Ushul Figh. Kairo: Dar al-Fikr, 1957. 